\title{
Aplikasi Kajian Islam Berbasis Android (Kajian Yuk)
}

\author{
Wahyu Purnama Sari \\ Fakultas Teknik \\ Program Studi Informatika \\ Universitas Langlangbuana \\ wahyu.purnama@unla.ac.id \\ Azis Muhammad Ihsan \\ Fakultas Teknik \\ Program Studi Informatika \\ Universitas Langlangbuana \\ azis00028@gmail.com
}

\author{
Irwin Supriadi \\ Fakultas Teknik \\ Program Studi Informatika \\ Universitas Langlangbuana \\ irwinshared@gmail.com \\ Ibnu Abdil Barry \\ Fakultas Teknik \\ Program Studi Informatika \\ Universitas Langlangbuana \\ ibnuabdilbarry@gmail.com
}

\begin{abstract}
Abstrak - Dalam memenuhi kebutuhan masyarakat beragama islam di Bandung terhadap permintaan informasi seputar kajian islam, aplikasi Kajian Yuk hadir sebagai solusi. Tujuan aplikasi ini dibuat untuk memudahkan Dewan Kemakmuran Masjid (DKM) dalam menyebarluaskan informasi kajian yang akan diadakan kepada masyarakat dan memudahkan pengguna mendapatkan informasi seputar waktu dan lokasi kajian. Aplikasi Kajian Yuk yang dibuat menggunakan bahasa pemrograman Java, yang menggunakan penyimpanan basis data online yaitu firebase, serta memerlukan library untuk kebutuhan pemrogramannya, dan android studio digunakan untuk membuat aplikasi. Aplikasi ini juga bisa digunakan untuk melihat kajian hari ini, mencari kajian, dan akun sebagai fitur khusus pihak Dewan Kemakmuran Masjid (DKM).
\end{abstract}

Keywords: Android Studio, Firebase, Kajian Yuk, Java

\section{PENDAHULUAN}

Indonesia merupakan salah satu negara yang memiliki beranekaragam agama, salah satunya adalah agama Islam. Mayoritas penduduk Indonesia beragama Islam, ini diperkuat dengan sensus Badan Pusat Statistik (BPS) pada tahun 2010 penduduk yang menganut agama Islam mencapai angka 207,2 juta jiwa atau $87,18 \%$ dari total penduduk Indonesia. Muslimpro dalam webnya menuliskan bahwa Indonesia menjadi negara dengan umat muslim terbesar di atas Pakistan dan India.[1]

Bandung sebagai ibukota provinsi Jawa Barat, menjadi kota yang mayoritas penduduknya beragama Islam. Maraknya fenomena pemuda hijrah akhir-akhir ini di Bandung, ditandai dengan banyaknya kajiankajian seputar islam yang di selenggarakan diberbagai masjid, tidak terlepas juga dengan masjid Al-Munawwaroh 1, Al-Kautsar dan AlHidayah yang kerap menghadirkan event kajian di tiap minggunya. Masyarakat yang datang menghadiri kajian sedikit banyak di pengaruhi oleh peran media sosial dalam penyebarluasan informasi kajian. Pemanfataan teknologi informasi berupa media sosial digunakan sebagai salah satu fasilitas atau layanan untuk penyebarluasan informasi kajian Islam kepada masyarakat.

Pada saat ini, penyebarluasan informasi kajian Islam di masjid Al-Munawwaroh 1, AlKautsar dan Al-Hidayah terbatas dengan hanya menggunakan media sosial. Informasi yang disampaikan melalui media sosial masih bercampurbaur dengan informasi-informasi lainnya diluar kajian Islam, karena sifatnya masih menggunakan akun pribadi atau grup tertentu. Sehingga hanya masyarakat tertentu saja yang akan mendapatkan informasi kajian tersebut dan informasi kajian Islam belum menyebar secara menyeluruh. Tentunya hal ini akan mempersulit masyarakat lain untuk mendapatkan informasi kajian seputar yang akan diselenggarakan.

Untuk itu diperlukan sebuah aplikasi yang secara khusus dapat mengelola informasi seputar kajian islam Dengan demikian, kami mencoba membuat suatu aplikasi, sebagai wadah khusus untuk mengelola informasi kajian islam, sehingga informasi dapat dengan mudah di sebarluaskan dengan mudah didapat oleh masyarakat umum. Juga menjadi wadah bagi DKM masjid Al-Munawwaroh 1, Al-Kautsar dan Al-Hidayah untuk menyebarluaskan informasi kajian Islam yang ingin disampaikan kepada masyarakat.

Adapun tujuan penelitian ini adalah Untuk memudahkan pengguna mendapatkan informasi seputar waktu dan lokasi kajian. Dan untuk memudahkan Dewan Kemakmuran Masjid (DKM) dalam membagikan informasi kajian yang akan diadakan kepada masyarakat. 


\section{METODE}

\subsection{Metode Penelitian}

Metode penelitian yang digunakan untuk mengembangkan aplikasi ini adalah metode deskriptif. Menurut Suryabrata (2012), penelitian deskriptif adalah penelitian yang bermaksud untuk membuat pencandraan (deskripsi) mengenai situasisituasi atau kejadian-kejadian. Dalam arti penelitian deskriptif itu adalah akumulasi data dasar dalam cara deskriptif semata-mata tidak perlu mencari atau menerangkan saling berhubungan, mentest hipotesis, membuat ramalan, atau mendapatkan makna dan implikasi walaupun penelitian yang bertujuan untuk menemukan hal-hal tersebut dapat mencakup juga metode-metode deskriptif.[2]

\subsection{Metode Pengembangan Perangkat Lunak}

Metode pengembangan perangkat lunak yang digunakan yaitu dengan menggunakan metode prototyping. Menurut Pressman (2012), seringkali pelanggan mendefinisikan satu set tujuan umum untuk perangkat lunak, tetapi tidak mengidentifikasi persyaratan rinci untuk fungsi dan fitur. Di lain kasus, pengembang mungkin tidak yakin dari efisiensi dari sebuah algoritma, adaptasi dari sistem operasi, atau bentuk yang interaksi manusia-mesin harus ambil. Dalam hal ini, dan situasi lain, paradigma prototipe mungkin menawarkan pendekatan yang terbaik. [3]

Metode prototyping dijelaskan pada gambar 1.

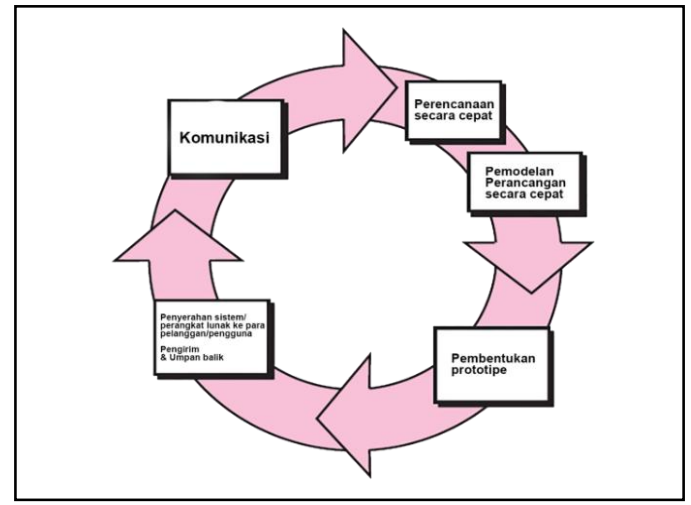

Gambar 1. Metode Prototyping (Pressman, 2012)

Berikut adalah tahapan dalam metode prototyping:

1. Komunikasi antara team pengembang perangkat lunak dengan para pelanggan. Team pengembang perangkat lunak akan melakukan pertemuan-pertemuan dengan para stakeholder untuk mendefinisikan sasaran keseluruhan untuk perangkat lunak yang akan dikembangkan, mengidentifikasi spesifikasi kebutuhan apapun yang saat ini diketahui, dan menggambar areaarea dimana definisi lebih jauh pada iterasi selanjutnya merupakan keharusan. Aktivitas yang dilakukan dalam pendefinisian spesifikasi kebutuhan yaitu dengan cara:
a. Survey
b. Wawancara
c. Studi literatur

2. Perancangan secara cepat berfokus pada representasi semua aspek perangkat lunak yang akan terlihat oleh para pengguna akhir (misalnya rancangan antar muka pengguna atau format tampilan). Aktivitas yang dilakukan dalam pernacangan secara cepat ini adalah melakukan perancangan sistem.

3. Pembentukan Prototipe dilakukan dari hasil rancangan cepat (quick design). Aktivitas yang dilakukan dalam pembentukan prototipe adalah merancang model dengan menggunakan metode berorientasi objek (Usecase diagram, Activity diagram, sequence diagram, Class diagram). Dan menerjemahkan dari perancangan sistem kedalam bahasa pemrograman yang digunakan adalah java, android studio, library, firebase.

4. Prototipe kemudian akan diserahkan kepada para stakeholder dan kemudian mereka akan melakukan evaluasi-evaluasi tertentu terhadap prototipe yang telah dibuat sebelumnya, kemudian akhirnya akan memberikan umpanbalik yang akan digunakan untuk memperhalus spesifikasi kebutuhan.

\section{HASIL DAN DISKUSI}

\subsection{Analisis}

Dari latar belakang yang telah dikemukakan bahwa sistem kajian saat ini yang masih bersifat manual dan belum ada aplikasi yang menunjang kajian yang ada di DKM wilayah Bandung, sehingga informasi kajian terbatas hanya pada komunitas tertentu saja. Maka perlu di bangun sebuah aplikasi untuk mendukung penyebarluasan kajian agar dapat menjadi alternatif masyarakat untuk dapat mengikuti kajian di wilayah Bandung. Aplikasi Kajian Yuk di bangun berbasis android, dimana sangat diharapkan dengan sifat mobile yang dimiliki maka informasi kajian sekitar Bandung dapat di akses oleh seluruh masyarakat di manapun selama terkoneksi dengan internet. 


\subsection{Perancangan}

\subsubsection{Perancangan Arsitektur Infrastruktur}

Arsitektur infrastuktur aplikasi menggambarkan tentang interaksi antara Dewan Kemakmuran Masjid (DKM) dengan pengguna yang dikelola oleh admin aplikasi. Admin bertugas untuk melakukan Upload terhadap informasiinformasi kajian akan dilaksanakan. Informasi kajian yang telah diUpload akan dapat diakses oleh masyarakat/pengguna. Adapun Arsitektur Infrastruktur yang akan di bangun dapat di jelaskan pada gambar 2 .

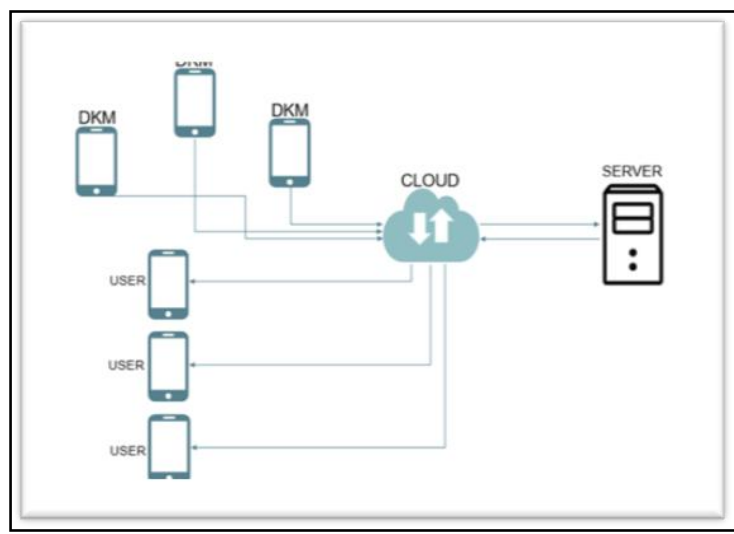

Gambar 2. Arsitektur Infrastuktur Aplikasi

Berikut tahapan proses interaksi dalam aplikasi:

a. Dewan Kemakmuran Masjid (DKM) memasukan informasi kajian yang akan dilaksanakan dan mengirimkan ke server.

b. Server menerima data dari DKM dan melakukan pengolahan informasi kajian yang masuk.

C. Server membagikan/menyebarluaskan informasi kajian kedalam aplikasi.

d. User Menerima Informasi Kajian dari Aplikasi.

\subsubsection{Perancangan Orientasi Objek}

Perancangan yang digunakan adalah Orientasi Objek Unified Modelling Language (UML). Terdapat empat diagram dalam UML yaitu Usecase Diagram, Sequence Diagram, Activity Diagram dan Class Diagram.

a. Usecase Diagram

Usecase Diagram merupakan aliran kegiatan dan proses bisnis yang dilakukan oleh pengguna (aktor)[4]. Diagram usecase dijelaskan pada gambar 3 .

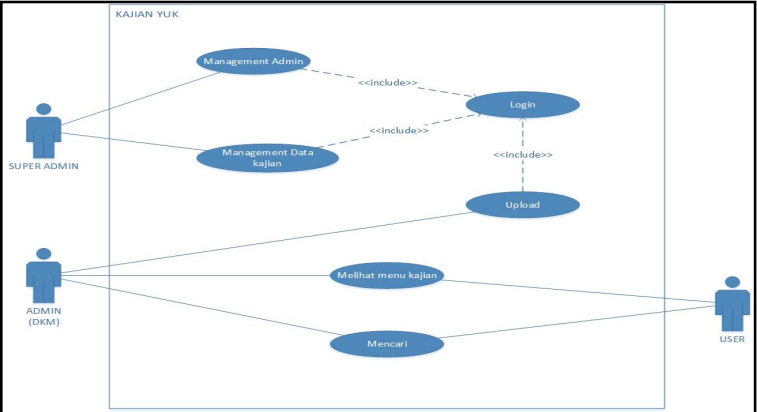

Gambar 3. Usecase Diagram

b. Sequence Diagram

Sequence Diagram menggambarkan kelakuan objek pada use case dengan mendeskripsikan waktu hidup objek dan pesan yang dikirimkan dan diterima antar objek [5]. Sequence diagram ini ditunjukan pada gambar 4 sampai dengan gambar 9.

a) Manajemen Admin

Sequence diagram manajemen admin ditunjukkan pada gambar 4.

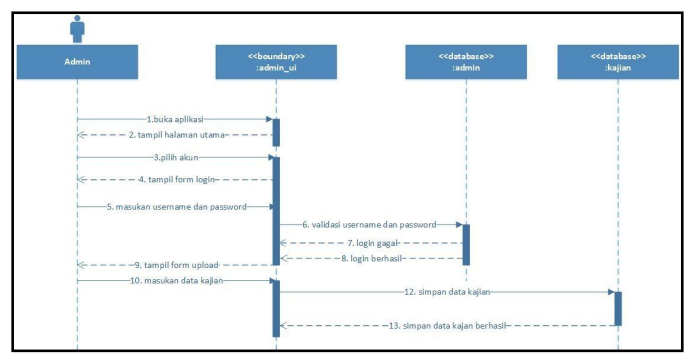

Gambar 4. Manajemen Admin

b) Managemen Data

Sequence diagram manajemen data ditunjukkan pada gambar 5 .

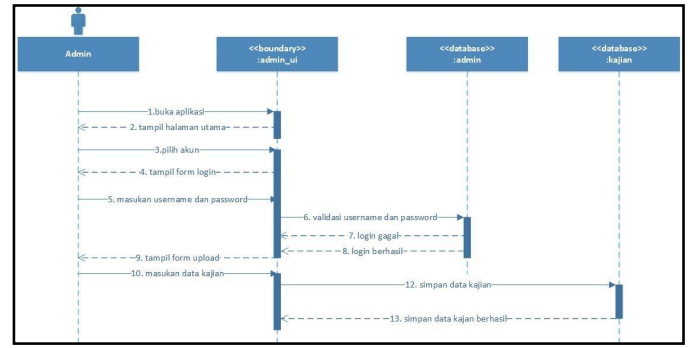

Gambar 5. Manajemen Data

c) Upload

Sequence diagram Upload ditunjukkan pada gambar 5. 


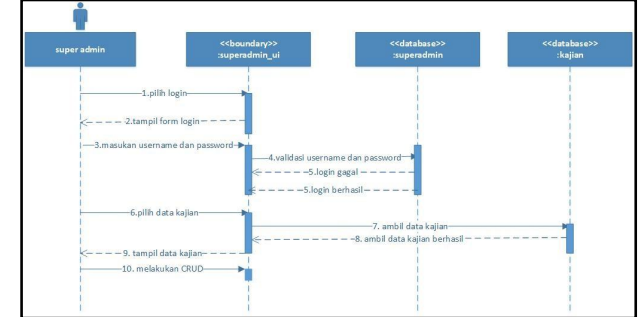

Gambar 5. Sequence diagram Upload

d) Sequence diagram Login ditunjukkan pada gambar 6.

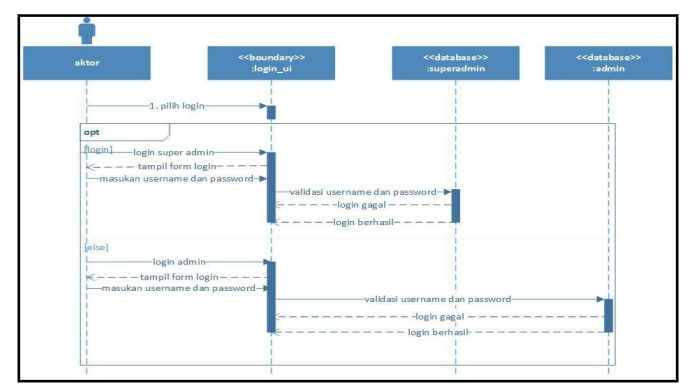

Gambar 6. Sequence diagram Login

e) Melihat Menu Kajian

Sequence diagram melihat menu kajian ditunjukkan pada gambar 7 .

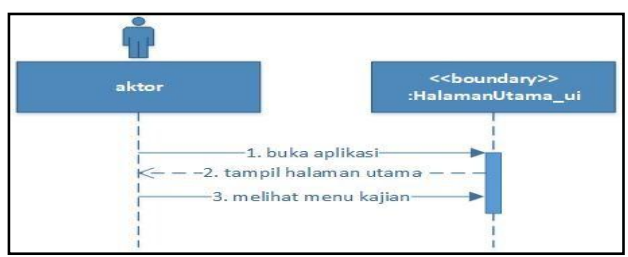

Gambar 7. Melihat Menu Kajian

f) Mencari

Sequence diagram mencari ditunjukkan pada gambar 8 .

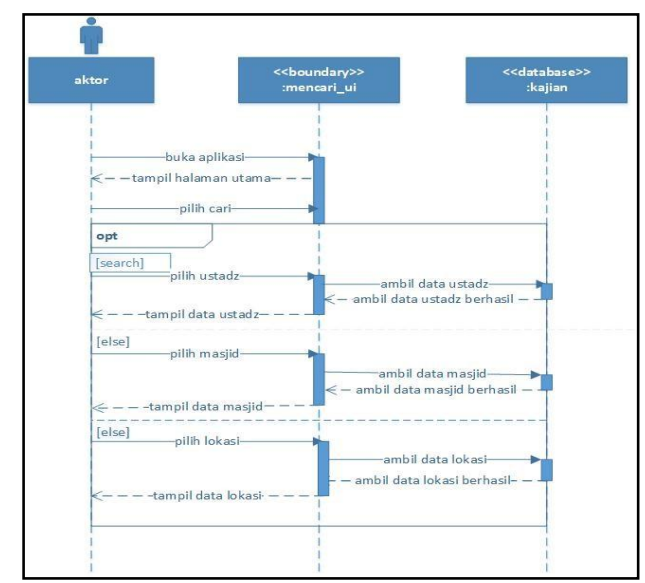

Gambar 8. Mencari

\section{Activity Diagram}

Activity diagram menggambarkan aliran kerja atau aktifitas dari sebuah sistem atau proses bisnis atau menu yang ada pada perangkat lunak [5]. Activity diagram ini ditunjukkan pada gambar 9 sampai dengan gambar 14.

a) Manajemen Admin

Activity Diagram Manajemen Admin ditunjukkan pada gambar 9.

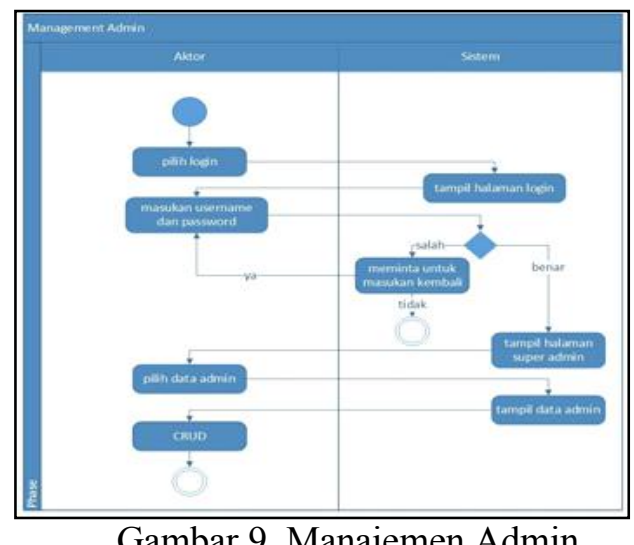

Gambar 9. Manajemen Admin

b) Manajemen Data Kajian

Activity Diagram Manajemen Data kajian ditunjukkan pada gambar 10.

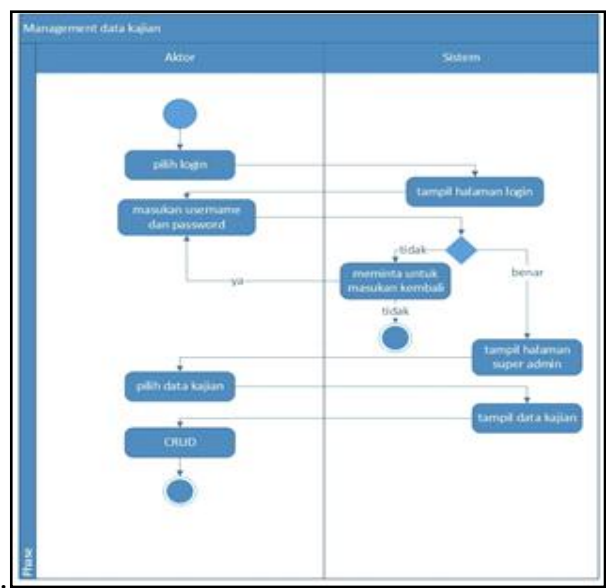

Gambar 10. Manajemen Data Kajian

c) Upload Kajian

Activity Diagram Upload ditunjukkan pada gambar 11. 


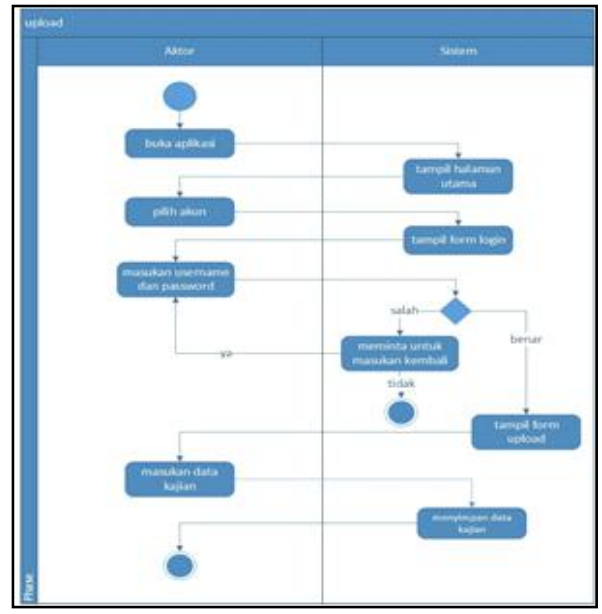

Gambar 11. Upload

d) Login

Activity Diagram Login ditunjukkan pada gambar 12.

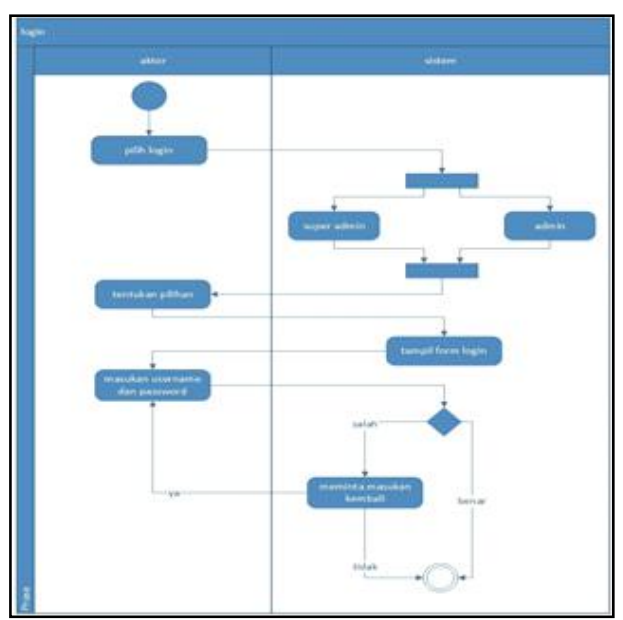

Gambar 12. Login

e) Melihat Menu Kajian

Activity Diagram melihat menu kajian ditunjukkan pada gambar 13 .

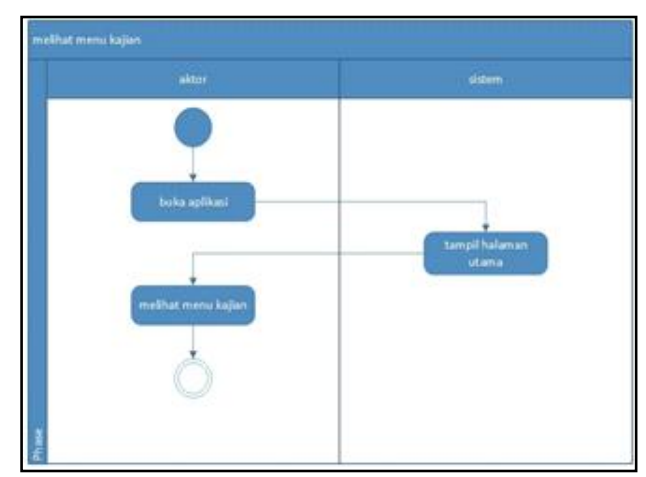

Gambar 13. Melihat Menu Kajian f) Mencari Kajian

Activity Diagram mencari Kajian ditunjukkan pada gambar 14 .

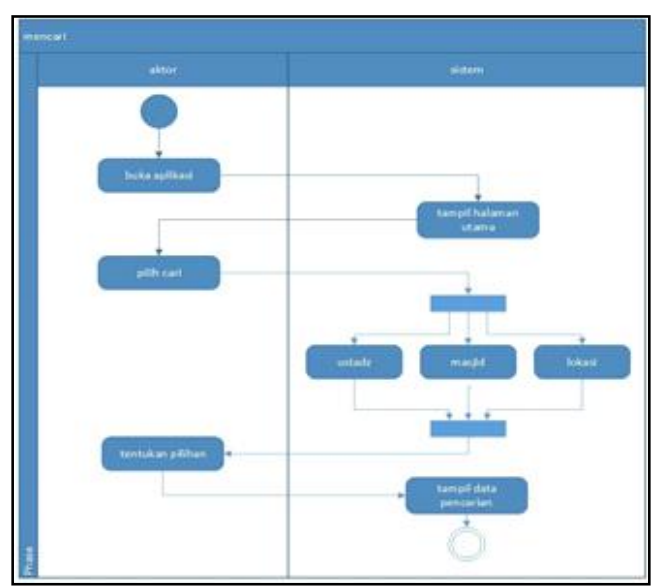

Gambar 14. Mencari Kajian

\section{d. Class Diagram}

Class diagram menggambarkan struktur sistem dari segi pendefinisian kelas-kelas yang akan dibuat untuk membangun sistem. Kelas memiliki apa yang disebut atribut dan method atau operasi [5]. Class Diagram ini ditunjukkan pada gambar 15 .

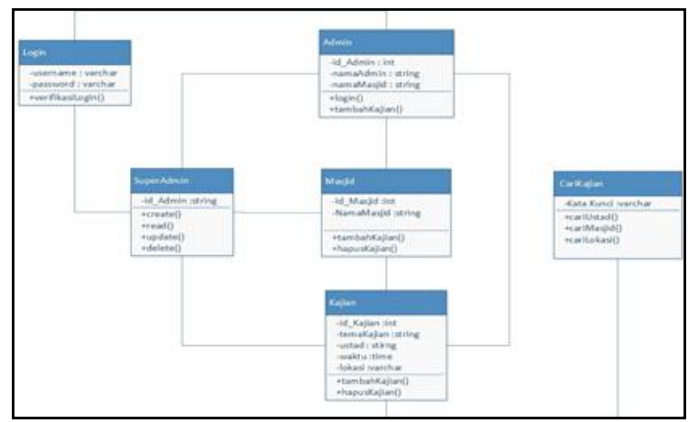

Gambar 15. Diagram Class

\subsubsection{Perancangan Sistem}

Perancangan sistem yaitu rancangan atau susunan sistem yang akan di bangun secara rinci bagaimana sistem akan berjalan. Perancangan sistem ini ditunjukkan pada gambar 15 sampai dengan gambar 24 .

\section{a. Interface Halaman Awal}

Pada halaman ini, merupakan tampilan awal sebelum masuk kedalam penggunaan fitur-fitur aplikasi kajian yuk. Interface halaman awal ditunjukan pada gambar 15 . 


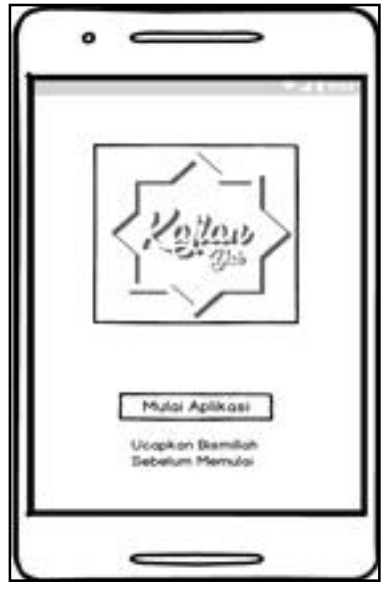

Gambar 15. Interface Halaman Awal

\section{b. Interface Menu Utama}

Pada halaman ini, user dapat melihat kajian-kajian yang diadakan. Juga dapat meilhat informasi secara detail dari setiap pampletnya. Interface Menu Utama ditunjukkan pada gambar 16.

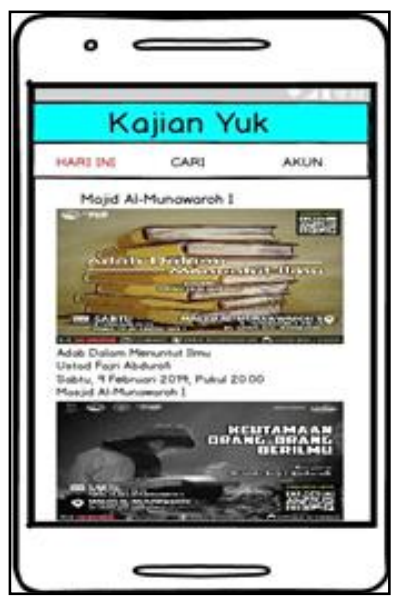

Gambar 16. Interface Menu Utama

\section{c. Interface Detail Kajian}

Pada halaman ini, merupakan detail informasi kajian yang disediakan setelah memilih pamplet kajian pada fitur hari ini. Interface detail kajian ditunjukkan pada gambar 17.

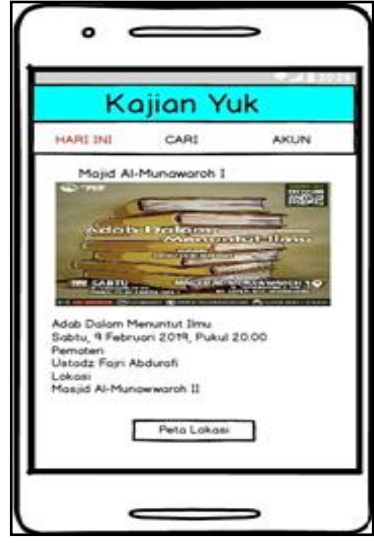

Gambar 17. Interface Detail Kajian

\section{d. Interface Penelusuran Lokasi Kajian}

Pada halaman ini, merupakan tampilan penelurusan lokasi kajian dari pamplet kajian hari ini yang di pilih oleh user. Interface penelusuran lokasi kajian ditunjukkan pada gambar 18 .

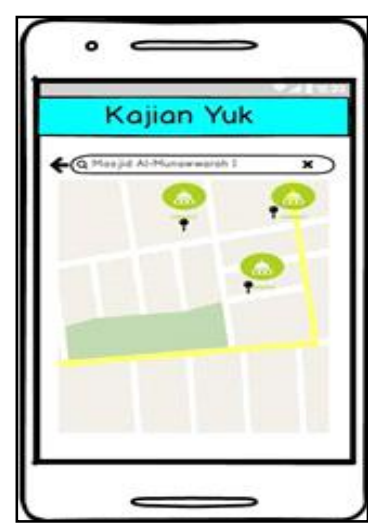

Gambar 18. Interface Penelusuran Lokasi

\section{e. Interface Fitur Cari}

Pada halaman ini merupakan bagian fitur cari, dimana user dapat melakukan pencarian terhadap ustad, masjid, dan lokasi kajian. Interface fitur Cari ditunjukkan pada gambar 19 . 


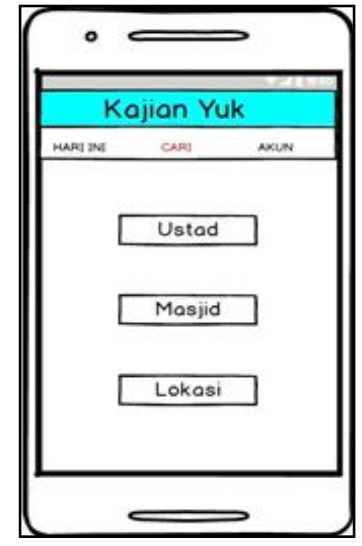

Gambar 19. Interface Fitur Cari

\section{f. Interface Pencarian Ustad}

Pada halaman ini, user dapat melakukan pencarian terhadap ustad. dan dapat melihat jadwal kajian ustad yang dicari. Interface pencarian ustad ditunjukkan pada gambar 20 .
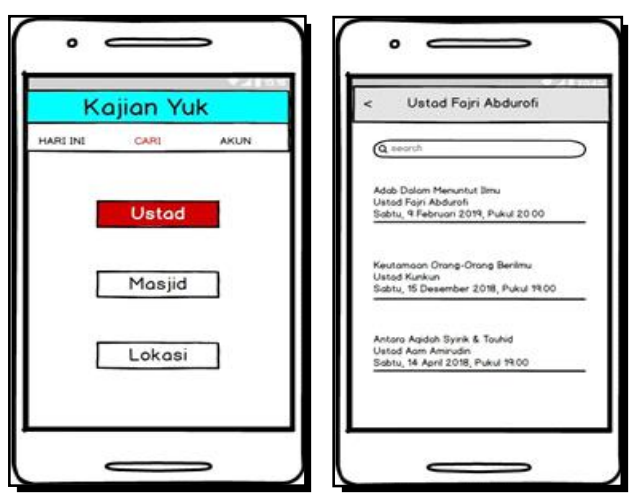

Gambar 20. Interface Pencarian Ustad

\section{g. Interface Cari Masjid}

Pada halaman ini, user dapat melakukan pencarian masjid dan dapat melihat jadwal kajian-kajian di masjid. Interface cari masjid ditunjukkan pada gambar 21.
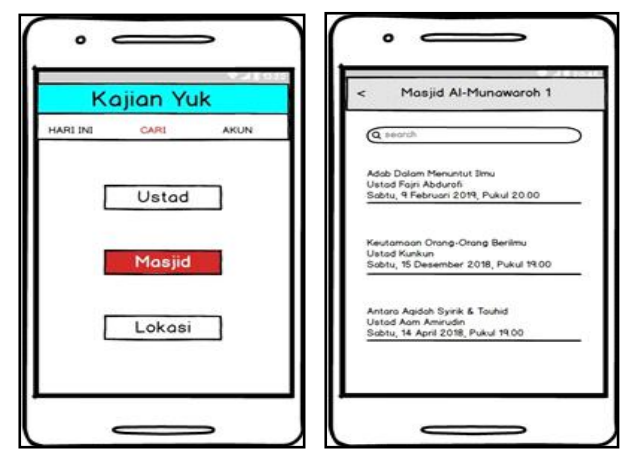

Gambar 21. Interface Cari Masjid

\section{h. Interface Cari Lokasi}

Pada halaman ini, user dapat melakukan pencarian lokasi masjid. Interface cari lokasi kajian ditunjukkan pada gambar 22.

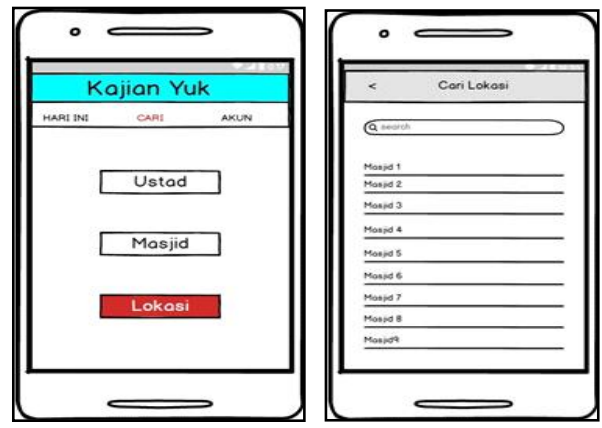

Gambar 22. Interface Cari Lokasi

i. Interface Form Login

Pada halaman ini, admin dapat melakukan login dengan mengisi form yang disediakan untuk selanjutkan dapat melakukan upload jadwal kajian baru. Interface form login ditunjukkan pada gambar 23.

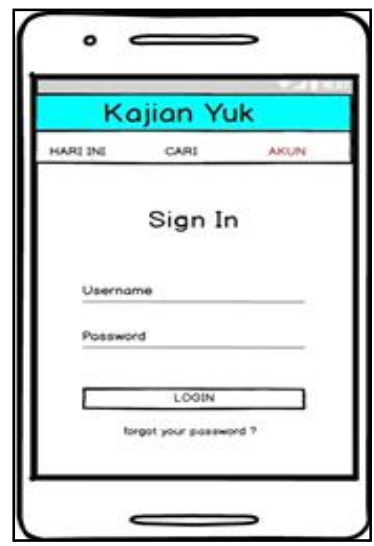

Gambar 23. Interface Form Login

\section{j. Interface Form Upload}

Pada halaman ini, admin diminta untuk mengisi form upload. Interface form upload ditunjukkan pada gambar 24 . 


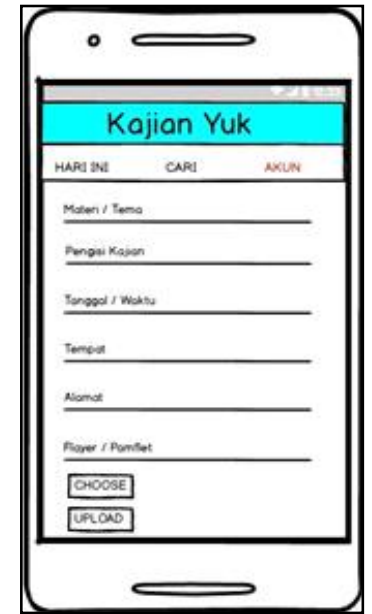

Gambar 24. Interface Form Upload

\section{KESIMPULAN}

Berdasarkan hasil penelitian ini, dapat disimpulkan beberapa hal mengenai aplikasi Kajian Yuk:

1. Tingkat tersampaikannya informasi pada masyarakat mengenai kajian di Indonesia khususnya di Bandung berada dalam taraf sedang.

2. Aplikasi Kajian Yuk merupakan aplikasi smartphone android yang dikembangkan berdasarkan kebutuhan masyarakan akan informasi mengenai kajian Islam.

3. Aplikasi Kajian Yuk mampu memberikan informasi tentang kajian yaitu informasi lokasi masjid, waktu kajian, ustadz dan tema kajian.

\section{UCAPAN TERIMAKASIH}

Alhamdulillaah kami ucapkan kepada Allah Subhanahuwata'ala atas kesehatan dan kelancaran, sehingga kami dapat menyelesaikan laporan penelitian ini. Beserta seluruh Civitas Akademik Universitas Langlangbuana atas dukungan dan Motivasinya.

\section{DAFTAR PUSTAKA}

[1] www.support. muslimpro.com, diakses pada 17 Januari 2019, pukul 20.00 WIB

[2] Suryabrata, Sumadi. Metodologi Penelitian. Jakarta. Rajagrafindo Persada. 2012.

[3] Pressman, Roger, S. Rekayasa Perangkat Lunak Pendekatan Praktisi Edisi 7. Yogyakarta. Andi. 2012

[4] Pratama, Agus Eka. Sistem Informasi dan Implementasinya. Bandung. Informatika. 2014

[5] Rosa A.S, dan M. Shalahuddin. Rekayasa Perangkat Lunak Struktur dan Berorientasi Objek. Bandung. Informatika. 2014. 